\title{
Parental disciplining and children behaviours: A review
}

\author{
K. Sobita Devi \\ DM College of Teacher Education, Imphal, Manipur, India.
}

\begin{abstract}
Disciplining is an aspect of parenting and has different ways of administration. They are a reflection of the parenting dimensions or the parenting typologies evolved from the combination of the dimensions. The paper reviews the available research and literature on parenting dimensions and parenting typologies and their impacts on children's behavioural outcomes. The paper also discusses the disciplinary practices adopted by the parents with special emphasis on corporal punishment vis-a-vis with children's moral internalisation and behavioural outcomes. Authoritative style of parenting is considered the most advantageous form of parenting. Psychological control and corporal punishment are associated with undesirable behavioural outcomes.
\end{abstract}

Keywords: Parenting dimensions, parenting typologies, corporal punishment, children behaviour.

\section{Introduction}

Disciplining is a universal aspect of socialisation strategies adopted by parents and caregivers in all cultures to teach children the values and normative behaviours of their society [1]. Disciplinary practices may be either power-assertive (physical punishment, threats or withdrawal of privileges), love-withdrawal (withholding attention, affection or approval) or inductive (reasoning, reminding children the rules and explaining the impact of children's behaviour on others). The way a child is disciplined is an indicator of the parenting styles adopted by the parents and is an area of contention with the anti-spanking rhetoric countered by the Christian fundamentalist of strict and sometimes punitive parental authority [2]. Diana Baumrind [4 and 5] postulated three parenting models i.e. authoritative, authoritarian, and permissive. Another two key dimensions of parenting: responsiveness and demandingness were put forward by Maccoby \& Martin [3]. Responsiveness is the extent of parental warmth, acceptance and involvement, while demandingness is the extent to which parents are strict or controlling [6,7 and 8]. The amalgamation of the extent of these two key dimensions with the tripartite model of Baumrind evolves the four-typology model of parenting:

Authoritative parents: They are both demanding and responsive. They monitor and impart clear standards for their children's conduct. They are assertive, but not intrusive and restrictive. Their disciplinary methods are supportive, rather than punitive. They want their children to be assertive, socially responsible, self regulated and cooperative. Authoritative parents encourage verbal give and take, and share with the child reasoning behind their policy. They exert firm control at points of parent child divergence, but do not hem in the child $[9,4$ and $10]$.

Authoritarian parents: They are highly demanding but not responsive. They expect their orders to be obeyed without explanation. These parents provide well-ordered and structured environments with clearly stated rules. They favour punitive and forceful measures to curb self-will at points where the child's actions or beliefs conflict with what they think is right conduct. They do not encourage verbal give and take, believing that the child should accept their word for what is right [9, 4 and 10].

Permissive parents: They are highly responsive but not demanding or directive. They are non-traditional and lenient, do not require mature behaviour, allow considerable self regulation, and avoid confrontation. They set no rules or standards for their children and don't hold them accountable for their actions [9, 4 and 10].

Uninvolved parents: They are neither responsive nor demanding. Uninvolved parents may be emotionally detached and depressed due to many stresses in their lives that they have no time for their children. They don't seem to care what their children do or what they become [3].

Barber et al. [11] identified three dimensions of parenting that appear to characterise parental influence across multi-cultural samples including both industrialised and non-industrialised countries. Parental support refers to varied parents' behaviours with affective, nurturing or companionate qualities. Psychological control refers to parents' actions that attempt to intrude into the psychological and emotional development of the child (e.g. thinking processes, self-expression, emotions, and attachment to parents) through guilt induction, withdrawal of 
love and affection, or shaming [12]. Behavioural control (e.g. maturity demands, monitoring, limit setting, etc.) consists of the regulation of the child's behaviour through firm and consistent discipline [13]. Authoritative as well as authoritarian parents are equally high in behavioural control. But authoritarian parents have excessively high expectations with little consideration on the child's capacities and resort to psychological control also when they are dissatisfied with the child [14].

\section{Parenting And Children Behaviours}

Parenting is associated with problem behaviours in many children. Problem behaviours in children are manifested either as externalising or internalising behaviours. In externalising problem behaviours, negative emotions manifested as anger, aggression, and frustration are directed against others [15 and 16]. On the other hand, in internalising problem behaviours negative emotions are directed at oneself rather than at others in the form of withdrawal, fearfulness, inhibition, and anxiety [17 and 15]. Studies on parental support, behavioural control and psychological control have each been shown to be associated with child and adolescent problem behaviours. A high level of behavioural control is related to low levels of externalising problems, such as antisocial behaviour and conduct disorders, both among adolescents [18, 19, 20 and 21] and among elementary school children [22 and 12]. It is widely accepted that parental affection facilitates children's adjustment [22 and 23]. However, there is some contradiction on the findings on parental affection to children's behaviours. Miller et al. [24] and Dodge, Pettit et al. [25] found that maternal warmth was negatively related to externalising problems among preschoolers, whereas Stice and Barrera [18] and Galambos et al. [13] showed that parental support was not related to adolescents' problem behaviours. Psychological control is associated with internalising problems, such as depressed mood and anxiety, among both adolescents [12, 26, 25 and 27] and children [22, 14 and 28]. Some studies have also found an association between high levels of psychological control and externalising problem behaviours [14 and 29]. There are some inconsistent findings on the association of children behavioural outcome with permutation of the parenting dimensions. Forehand \& Nousiainen [30] and Gray \& Steinberg [23] found that affection promoted adolescents' psychosocial development, particularly when combined with a high level of behavioural control. Gray \& Steinberg [23] also found that, among adolescents, parental affection prevented internal distress better when combined with a high level of psychological control than when it was combined with a high level of autonomy granting. They suggested that a high level of affection compensated for the negative effects of psychological control. In another study, Pettit \& Laird [21] found that a high level of psychological control combined with a low level of parental involvement was associated with delinquent behaviour among adolescents, whereas a high level of psychological control combined with a high level of parental involvement did not show such associations. Galambos et al. [13] found that a combination of high levels of psychological and behavioural controls was related to externalising problems (substance use, antisocial behaviour, and misconduct at school) among adolescents and suggested that behavioural control may not be uniformly effective if associated with other less desirable parenting. Interestingly, Aunola \& Nurmi [31] found that mothers high in psychological control together with a high level of affection appear to be the most detrimental combination for the development of problem behaviours among children. In the study, mothers' high behavioural control in combination with a low level of psychological control was shown to decrease children's external problem behaviours. One way or the other, the findings support the notion that it is not single parenting style variables as such, but rather their typology that is influential in child development [10 and 6]. The impact of parenting typology on children's development in the domains of social competence, psychosocial development, and problem behaviour has been documented in many studies. Some consistent outcomes are reported below.

- Children of the authoritative parents are the most well adjusted children [32 and 10]. They are friendly and exhibit high self-esteem, self-reliance, social and moral maturity [24, 33 and 34].

- Children of authoritarian parents are anxious, withdrawn, mistrusting and unhappy [10 and 14] and therefore, have social-emotional difficulties. They are low in self-esteem and self-reliance and react with hostility when confronted [3, 35, 36, 37 and 27].

- Children of permissive parents are impulsive, demanding, disobedient and rebellious [10 and 19]. They are aggressive with the peers and engage in delinquent activities as adolescents but have higher selfesteem than authoritarian parents [38].

- Children and adolescents of uninvolved parents perform most poorly in all domains [38].

Authoritative parenting style is generally considered advantageous to many aspects of child development [5 and 38]. In contrast, parents who tend to be coercive, harsh, and arbitrarily authoritarian or power assertive in their parenting practices are less likely to be successful than those who place substantial emphasis on reasoning in an attempt to be responsive to and understanding of their child's point of view [39]. The four-typology parenting model has often been criticized because of the difficulty associated with assigning a parent to a single style as 
parents tend to employ different child rearing approaches at different times, under different circumstances, and with different children. Also, Chao [40] is of the opinion that the typologies reflect historical influences and beliefs regarding the raising of children in the Western milieu and are unsuitable for families of Asian descent. Here, Pecnic [41] describes four parenting practices that have been identified as facilitating more positive experiences. Nurturing behaviour refers to activities that respond to the child's needs for emotional security, such as the provision of warmth and sensitivity within the relationship. Structure refers to setting boundaries and guiding the child's behaviour through modelling of positive behaviours, without physical or psychological coercion. Recognition refers to the child's need to be respected and acknowledged by parents and to foster the potential for mutual understanding and influence to develop. Finally, empowerment refers to combining a sense of personal control with the ability to affect the behaviour of others. It is a process of parental adjustment to the changing developmental tasks of children as they grow older.

\section{Disciplining And Moral Internalisation}

Grusec \& Goodnow [39] defined moral internalization as "taking over the values and attitudes of society as one's own so that socially acceptable behaviour is motivated not by anticipation of external consequences but by intrinsic or internal factors" and it underlies the development of children's social and emotional competence [42]. Hoffman's [43] theory of moral internalisation attempts to address how societal norms and parental values, which are initially motivated by external forces (e.g. fear of sanction), eventually come to acquire an internal motivational force. He argues that disciplinary encounters with parents are central to this process of moral internalisation and what happens in a disciplinary encounter is likely to influence whether or not children internalise norms and subsequently behave in a way that is consistent with these norms. As children internalise norms of behaviour, the need for external control of behaviour through mechanisms such as reward and punishment is lessened [46]. Grusec \& Goodnow [39] is of the opinion that the use of punishment or other power-assertive techniques is less effective than the processes of reasoning or induction in promoting internalisation. Hoffman [44 and 43] asserts that power-assertive techniques are detrimental to socialisation because they arouse fear and anxiety in the child, provide a model of aggression to the child, heighten the child's view that the moral standard is external to the self, and direct the child's attention to the consequences of the behaviour for the self rather than for other people. In contrast, parents who use inductive techniques point out the effect of the child's behaviour on others and may suggest reparative actions. Hoffman [45 and 44] argues that such inductions promote internalisation because they develop the child's empathic capacities and induce negative feelings from which the child cannot escape even when the parent is no longer present. Inductions are also unlikely to produce high levels of anxiety or fear, and so the child is able to attend to, and process the information embedded in the parent's inductive statement. Disciplinary strategies should promote a moderate level of arousal in the child [46]. Too much arousal may result in fear and anxiety, which will direct attention away from the parent's message to the consequence for the self. On the other hand, too little arousal may result in the child not attending to the parental message at all. Power-oriented forceful discipline undermines internalisation by eliciting very high anxiety or arousal in the child and interfering with the effective processing of the parental message about behavioural standards [42].

\section{Corporal Punishment And Children Behaviour}

Corporal or physical punishment is the use of physical force, no matter how light, with the intention of causing the child to experience bodily pain or discomfort but not injury so as to correct or punish the child's behaviour [47, 48 and 49]. Such physical force typically includes hitting children either with a hand or with an object and is known by a variety of euphemisms such as spank, smack, slap, pop, beat, paddle, punch, whip, and hit [50 and 51]. There is a varying concept on the administration of corporal punishments with those who argue that corporal punishment in some circumstances is effective and sometimes necessary to discipline children [2 and 52] and those who assert that there is very little benefit and rather a substantial risk of harm from using corporal punishment on children [53, 54, 47, 55]. Hoffman [44], Grusec [56] and Smetana [57] are of the view that corporal punishment does not teach children the reasons for behaving correctly or the effects of their behaviors on others; rather it may teach children the desirability of not getting caught. Over the years, several studies have concluded that corporal punishment is associated with increase in children's aggressive behaviours [58, 59 and 60]. This is because corporal punishment models aggression [61 and 62]; promotes hostile attributions, which predict violent behaviour [63]; and initiates coercive cycles of aversive behaviours between parent and child [64]. Corporal punishment can evoke feelings of fear, anxiety, and anger in children. It can interfere with the parent-child relationship by inciting the child fear and avoidance of the parent [39 and 3]. Harsh punishment method including corporal punishment has also been associated significantly with adolescents' depressive symptoms and distress [65]. Coercive techniques have been associated with decreases in children's feelings of confidence and assertiveness and with increases in feelings of humiliation and helplessness [66]. 
The primary goal of any socialization should be to promote children's internalisation for behaving appropriately rather than to behave solely for avoiding punishment [44 and 67]. Gershoff [55] carried out a comprehensive review and meta-analysis of 92 studies on corporal punishment carried out for over a period of 62 years and examined the association of corporal punishments with 11 child outcomes. On an average, he found a positive effect on the parents' use of corporal punishment with children's immediate compliance but the inferences were highly inconsistent with two of the five studies under meta-analysis showing association of corporal punishment with less immediate compliance. The meta-analysis of the remaining 10 outcomes indicated association of parental corporal punishment with the following undesirable behaviours and experiences: decreased moral internalisation, increased child aggression, increased child delinquent and antisocial behaviour, decreased quality of relationship between parent and child, decreased child mental health, increased risk of being a victim of physical abuse, increased adult aggression, increased adult criminal and antisocial behaviour, decreased adult mental health, and increased risk of abusing own child or spouse. Recent studies on the impacts of corporal punishment on children have found association with children's physical aggression, verbal aggression, physical fighting and bullying, antisocial behaviour and behavioural problems [68, 69, 70, 71, 72, 73, 74 and 75].

\section{Conclusion}

Authoritative parenting style is generally considered the optimum parenting style as it is mostly associated with positive children outcomes. Nevertheless, certain associations are emphasised in the literature, such as the links between parental warmth and inductive discipline strategies with higher levels of moral internalisation in children and, conversely, parental harshness such as corporal punishments and psychological control with negative behavioural outcomes for children.

\section{References}

[1] Wissow, L.S., Child Discipline in the First Three Years of Life in N. Halfon, K.T. McLearn and M.A. Schuster (Eds.), Childrearing in America: Challenges facing parents with young children (New York: Cambridge University Press, 2002) 146-177.

[2] Baumrind, D., A blanket injunction against disciplinary use of spanking is not warranted by the data. Pediatrics, $98(4$ Pt. 2) 1996, $828-831$.

[3] Maccoby, E. E., and Martin, J. A., Socialization in the context of the family: Parent-child interaction. In E. M. Hetherington (Ed.) and P. H. Mussen (Series Ed.), Handbook of child psychology: Vol. 4. Socialization, personality, and social development (New York: Wiley, 1983), 1-101.

[4] Baumrind, D., Child care practices anteceding three patterns of preschool behaviour, Genetic Psychology Monographs, 75, 1967, 43-88.

[5] Baumrind, D., Current theories of parental authority, Developmental Psychology Monographs, 4(1), 1971

[6] Darling, N., and Steinberg, L., Parenting style as context: An integrative model, Psychological Bulletin, 113, 1993, 487-496.

[7] Smetana, J. G., Parenting styles and conceptions of parental authority during adolescence, Child Development, 66, 1995, $299-316$.

[8] Steinberg, L., Psychological control: Style or substance? In J. G. Smetana (Ed.), New directions for child and adolescent development: Changes in parental authority during adolescence (San Francisco: Jossey- Bass, 2005), 71-78.

[9] Baumrind, D., Effects of authoritative parental control on child behaviour, Child Development, 37, 1966, 887 - 907.

[10] Baumrind, D., The influence of parenting style on adolescent competence and substance use. Journal of Early Adolescence, 11, 1991, 56-95.

[11] Barber, B., Stolz, H. and Olsen, J., Parental Support, Psychological Control and Behavioural Control: Assessing relevance across time, culture and method, Monographs of the Society for Research in Child Development, 70 (4), 2005.

[12] Barber, B. K., Parental psychological control: Revisiting a neglected construct, Child Development, 67, 1996, 3296 - 3319.

[13] Galambos, N. L., Barker, E. T., \& Almeida, D. M., Parents do matter: Trajectories of change in externalizing and internalizing problems in early adolescence, Child \& Adolescent Psychiatry, 7, 2003, $125-130$.

[14] Barber, B. K., and Harmon, E. L., Violating the self: Parental psychological control of children and adolescents, in B. K. Barber (Ed.), Intrusive parenting. How psychological control affects children and adolescents (Washington, DC: American Psychological Association, 2002), 15-52.

[15] Kovacs, M., and Devlin, B., Internalizing disorders in childhood. Journal of Child Psychology and Psychiatry, 39, 1998, 47 - 63.

[16] Roeser, R., Eccles, J., and Strobel, K., Linking the study of schooling and mental health: Selected issues and empirical illustrations at the level of the individual, Educational Psychologist, 33, 1998, 153-176.

[17] Eisenberg, N., Losoya, S. and Fabes, R.A., Parental socialization of children's deregulated expression of emotion and externalizing problems, Journal of Family Psychology, 15, 2001, 183-205.

[18] Stice, E., and Barrera, M., A longitudinal examination of the reciprocal relations between perceived parenting and adolescents' substance use and externalizing behaviours, Developmental Psychology, 31, 1995, $322-334$.

[19] Barber, B. K., and Olsen, J. A., Socialization in context: Connection, regulation, and autonomy in the family, school, and neighbourhood, and with peers. Journal of Adolescent Research, 12, 1997, 287 - 315.

[20] Eccles, J. S., Early, D., Frasier, K., Belansky, E., and McCarthy, K., The relation of connection, regulation, and support for autonomy to adolescents' functioning. Journal of Adolescent Research, 12, 1997, $263-286$.

[21] Pettit, G. S., and Laird, R. D. (2002). Psychological control and monitoring in early adolescence: The role of parental involvement and earlier child adjustment in B. K. Barber (Ed.), Intrusive parenting. How psychological control affects children and adolescents (Washington, DC: American Psychological Association, 2002), 97-123.

[22] Siequeland, L., Kendall, P. C., and Steinberg, L., Anxiety in children: Perceived family environments and observed family interaction, Journal of Clinical Child Psychology, 25, 1996, 225-237.

[23] Gray, M. R., and Steinberg, L., Unpacking authoritative parenting: Reassessing a multidimensional construct. Journal of Marriage and the Family, 61, 1999, $574-587$.

[24] Miller, N. B., Cowan, P. A., Cowan, C. P., Hetherington, E. M., and Clingempeel, W. G., Externalizing in preschoolers and early adolescents: A cross-study replication of a family model, Developmental Psychology, 29(1), 1993, 3-18. 
[25] Dodge, K. A., Pettit, G. S., and Bates, J. E., Socialization mediators of the relation between socioeconomic status and child conduct problems. Child Development, 65, 1994, 649-665.

[26] Conger, K. J., Conger, R. D., and Scaramella, L. V., Parents, siblings, psychological control, and adolescent adjustment. Journal of Adolescent Research, 12, 1997, $113-138$.

[27] Wolfradt, U., Hempel, S., and Miles, J. N. V., Perceived parenting styles, depersonalisation, anxiety and coping behaviour in adolescents, Personality and Individual Differences, 34, 2003, $521-532$.

[28] Olsen, S. F., Yang, C., Hart, C. H., Robinson, C. C., Wu, P., and Nelson, D. A., Maternal psychological control and preschool children's behavioral outcomes in China, Russia, and the United States in B. K. Barber (Ed.), Intrusive parenting: How psychological control affects children and adolescents, (Washington, DC: American Psychological Association, 2002 ), $235-262$.

[29] Yang, C., Hart, C. H., Nelson, D. A., Porter, C. L., Olsen, S.F., and Robinson, C. C., Fathering in a Beijing, Chinese sample Associations with boys' and girls' negative emotionality and aggression in R. D. Day \& M. E. Lamb (Eds.), Conceptualizing and measuring father involvement, (Mahwah, NJ: Laurence Erlbaum Associates, 2004), 185-215.

[30] Forehand, R., and Nousiainen, S., Maternal and paternal parenting: Critical dimensions in adolescent functioning. Journal of Family Psychology, 7, 1993, $213-221$.

[31] Aunola, K. and Nurmi, J., The role of parenting styles in children's problem behaviour, Child Development, 76 (6), 2005,1144 1159 .

[32] Baumrind, D., Rearing competent children in W. Damon (Ed.), Child development today and tomorrow, (San Francisco: JosseyBass, 1989), 349-378.

[33] Weiss, L. H., and Schwarz, J. C., The relationship between parenting types and older adolescents' personality, academic achievement, adjustment, and substance use. Child Development, 67(5), 1996.

[34] Amato, P. R., and Fowler, F., Parenting practices, child adjustment, and family diversity, Journal of Marriage and the Family, 64, 2002, 703-716.

[35] Coopersmith, S., The antecedent of self-esteem (San Francisco: Freeman, 1967).

[36] Coie, J. D., and Dodge, K. A., Aggression and antisocial behaviour in W. Damon (Series Ed.) and N. Eisenberg (Vol. Ed), Handbook of Child Psychology: Vol 3. Social, emotional and personality development, (New York: Wiley, 1998), 779-862.

[37] Jewell, J. D., and Stark, K. D., Comparing the family environments of adolescents with conduct disorder and depression, Journal of Child and Family Studies, 12, 2003, 77 - 89.

[38] Lamborn, S. D., Mounts, N. S., Steinberg, L., and Dornbusch, S. M., Patterns of competence and adjustment among adolescents from authoritative, authoritarian, indulgent, and neglectful families, Child Development, 62, 1991, 1049-1065.

[39] Grusec, J. E., and Goodnow, J. J., Impact of parental discipline methods on the child's internalization of values: A reconceptualization of current points of view, Developmental Psychology, 30, 1994, 4-19.

[40] Chao, R. K., Beyond parental control and authoritarian parenting style: Understanding Chinese parenting through the cultural notion of training, Child Development, 65, 1994, 1111-1119.

[41] Pecnic, N., Towards a Vision of Parenting in the Best Interests of the Child, in M. Daly (ed.), Parenting in Contemporary Europe: A Positive Approach. (Strasbourg: Council of Europe, 2007).

[42] Kochanska, G. and Thompson, R.A., The emergence and development of conscience in toddlerhood and early childhood, in J.E. Grusec and L. Kuczynski (Eds.), Parenting and Children's Internalization of Values: A Handbook of Contemporary Theory. (New York: Wiley, 1997), 53-77.

[43] Hoffman, M.L., Empathy and Moral Development: Implications for caring and justice, (Cambridge: Cambridge University Press, 2000).

[44] Hoffman, M.L., Affective and Cognitive Processes in Moral Internalisation, in E.T. Higgins, D. Ruble and W. Hartup (Eds.), Social Cognition and Social Development: A Socio-Cultural Perspective, (Cambridge: Cambridge University Press, 1983), $236-74$.

[45] Hoffman, M.L., Moral Development in P.H. Mussen (Ed.), Carmichael's Manual of Child Psychology, 2, (New York: Wiley, 1970), 261-360

[46] Smith, A.B., Gollop, M., Taylor, N.J. and Marshall, K., The Discipline and Guidance of Children: A Summary of Research, (Dunedin and Wellington, NZ: Children's Issues Centre and Office of the Children's Commissioner, 2005).

[47] Straus, M. A., Beating the devil out of them: Corporal punishment in American families (2nd Ed.), (Piscataway, NJ: Transaction Publishers, 2001).

[48] Durrant, J., Corporal Punishment: Prevalence, predictors and implications for child behaviour and development in S.N. Hart (Ed.), Eliminating Corporal Punishment: The Way Forward to Constructive Child Discipline, (Paris: UNESCO, 2005), 49-90.

49 Bitensky, S. H., Corporal punishment of children: A human rights violation, (Ardsley, NY: Transnational Publishers, 2006)

[50] Davis, P. W., Threats of corporal punishment as verbal aggression: A naturalistic study, Child Abuse \& Neglect, 20, 1996, 289-304

[51] Mosby, L., Rawls, A. W., Meehan, A. J., Mays, E., and Pettinari, C. J., Troubles in interracial talk about discipline: An examination of African American child rearing narratives, Journal of Comparative Family Studies, 30, 1999, 489-521.

[52] Larzelere, R. E., Response to Oosterhuis: Empirically justified uses of spanking- Toward a discriminating view of corporal punishment, Journal of Psychology and Theology, 21, 1993, 142-147.

[53] Lytton, H., Correlates of compliance and the rudiments of conscience in two-year-old boys, Canadian Journal of Behavioral Science, 9, 1977, 242-251.

[54] McCord, J., On discipline, Psychological Inquiry, 8, 1997, 215-217

[55] Gershoff, E. T., Corporal punishment by parents and associated child behaviors and experiences: A meta-analytic and theoretical review, Psychological Bulletin, 128, 2002, 539-579.

[56] Grusec, J. E., The internalization of altruistic dispositions: A cognitive analysis, in E. T. Higgins, D. N. Ruble, \& W. W. Hartup (Eds.), Social cognition and social development, (New York: Cambridge University Press, 1983) 275-293.

[57] Smetana, J. G., Parenting and the development of social knowledge reconceptualized: A social domain analysis, in J. E. Grusec \& L. Kuczynski (Eds.), Parenting and children's internalization of values: A handbook of contemporary theory, (New York: Wiley, 1997), 162-192.

[58] Becker, W. C., Consequences of different models of parental discipline in M. L. Hoffman \& L. W. Hoffman (Eds.), Review of child development research (Vol. I), (New York: Sage, 1964), 169-208.

[59] Radke-Yarrow, M. R., Campbell, J. D., and Burton, R. V., Child rearing: An inquiry into research and methods. (San Francisco: Jossey- Bass, 1968)

[60] Patterson, G. R., Coercive family process, (Eugene, OR: Castalia, 1982).

[61] Aronfreed, J., The concept of internalization. In D. A. Goslin (Ed.), Handbook of socialization theory and research, (Chicago: Rand McNally, 1969), 263-323.

[62] Walters, G. C., \& Grusec, J. E., Punishment, (San Francisco: W. H. Freeman, 1977). 
[63] Dodge, K. A., Pettit, G. S., McClaskey, C. L., and Brown, M. M., Social competence in children, Monographs of the Society for Research in Child Development, 51(2) 1986.

[64] Dishion, T. J., and Patterson, G. R., Model building in developmental psychopathology: A pragmatic approach to understanding and intervention, Journal of Clinical Child Psychology, 28, 1999, 502-512.

[65] McLoyd, V. C., Jayaratne, T. E., Ceballo, R., and Borquez, J., Unemployment and work interruption among African American single mothers: Effects on parenting and adolescent socioemotional functioning, Child Development, 65, 1994, 562-589.

[66] Lasky, M. R., Family genesis of aggression, Psychiatric Annals, 23, 1993, 494-499.

[67] Lepper, M. R., Social control processes and the internalization of social values: An attributional perspective, in E. T. Higgins, D. N. Ruble, \& W. W. Hartup (Eds.), Social cognition and social development, (New York: Cambridge University Press, 1983), 294-330.

[68] Pagani, L. S., Tremblay, R. E., Nagin, D., Zoccolillo, M., Vitaro, F., and McDuff, P., Risk factor models for adolescent verbal and physical aggression toward mothers, International Journal of Behavioral Development, 28, 2004, 528-537.

[69] Gershoff, E. T., Grogan-Kaylor, A., Lansford, J. E., Chang, L., Dodge, K. A., Zelli, A., and Davis, S. M., Use of harsh physical discipline and developmental outcomes in adolescence, Development and Psychopathology, 19, 2007, 227-242.

[70] Lansford, J. E., Chang, L., Dodge, K. A., Malone, P. S., Oburu, P., Palme'rus, K., Physical discipline and children's adjustment: Cultural normativeness as a moderator, Child Development, 76, 2005, 1234-1246.

[71] Ohene, S. A., Ireland, M., McNeely, C., and Borowsky, I. W., Parental expectations, physical punishment, and violence among adolescents who score positive on a psychosocial screening test in primary care, Pediatrics, 117, 2006, 441-447.

[72] Grogan-Kaylor, A., The effect of corporal punishment on antisocial behavior in children, Social Work Research, 28, 2004, 153-162.

[73] Grogan-Kaylor, A., Corporal punishment and the growth trajectory of children's antisocial behaviour, Child Maltreatment, 10, 2005, 283-292.

[74] Javo, C., Rønning, J. A., Heyerdahl, S., \& Rudmin, F. W. (2004). Parenting correlates of child behavior problems in a multiethnic community sample of preschool children in northern Norway. European Child \& Adolescent Psychiatry, 13, 8-18.

[75] Kerr, D., Lopez, N., Olson, S., \& Sameroff, A. (2004). Parental discipline and externalizing behavior problems in early childhood: The roles of moral regulation and child gender. Journal of Abnormal Child Psychology, 32, 369-383. 